\title{
Stability of Uranium Incorporated into Fe(hydr)oxides Under Fluctuating Redox Conditions
}

\author{
Brandy D. Stewart ${ }^{1}$, Peter S. Nico ${ }^{2}$, and Scott Fendorf ${ }^{1^{*}}$
}

${ }^{1}$ Environmental Earth System Science, Stanford University, Stanford,
CA 94305, USA
${ }^{2}$ Earth Sciences Division, Lawrence Berkeley National Laboratory, Berkeley, CA 94720, USA

*Corresponding author

Email: Fendorf@stanford.edu

Phone: 650-723-5238 


\section{Abstract}

Reaction pathways resulting in uranium bearing solids that are stable (i.e., having limited solubility) under both aerobic and anaerobic conditions will limit dissolved concentrations and migration of this toxin. Here we examine the sorption mechanism and propensity for release of uranium reacted with $\mathrm{Fe}$ (hydr)oxides under cyclic oxidizing and reducing conditions. Upon reaction of ferrihydrite with $\mathrm{Fe}(\mathrm{II})$ under conditions where aqueous $\mathrm{Ca}-\mathrm{UO}_{2}-\mathrm{CO}_{3}$ species predominate ( $3 \mathrm{mM} \mathrm{Ca}$ and $3.8 \mathrm{mM} \mathrm{CO}_{3}$-total), dissolved uranium concentrations decrease from $0.16 \mathrm{mM}$ to below detection limit (BDL) after 5 to $15 \mathrm{~d}$, depending on the Fe(II) concentration. In systems undergoing 3 successive redox cycles ( $15 \mathrm{~d}$ of reduction followed by $5 \mathrm{~d}$ of oxidation) and a pulsed decrease to $0.15 \mathrm{mM} \mathrm{CO}_{3}$-total, dissolved uranium concentrations varied depending on the Fe(II) concentration during the initial and subsequent reduction phases- $\mathrm{U}$ concentrations resulting during the oxic 'rebound' varied inversely with the Fe(II) concentration during the reduction cycle. Uranium removed from solution remains in the oxidized form and is found both adsorbed on and incorporated into the structure of newly formed goethite and magnetite. Our results reveal that the fate of uranium is dependent on anaerobic/aerobic conditions, aqueous uranium speciation, and the fate of iron. 


\section{Introduction}

Uranium mining and enrichment processes have created an inventory of waste. Owing to both ecosystem and human health consequences, understanding reactions controlling uranium's partitioning on solids and the potential for migration is important. A redox active contaminant, uranium has two formal oxidation states. The oxidized state, U(VI), commonly exists as the uranyl ion $\mathrm{UO}_{2}{ }^{2+}$ (and associated complexes) in aqueous systems. Under anaerobic conditions, $\mathrm{U}(\mathrm{VI})$ may be reduced to U(IV), which subsequently forms the sparingly soluble $\mathrm{UO}_{2}$ phase, by dissimilatory metal reducing bacteria (DMRB) that couple uranium reduction with the oxidation of organic carbon or $\mathrm{H}_{2}$ (1-3). In fact, stimulated (through addition of a carbon source) reductive immobilization has been studied and implemented in field-scale contaminated zones as a potential means of uranium remediation (4-8). However, the presence of dissolved $\mathrm{Ca}$ and carbonate promotes the formation of ternary uranyl-calcium-carbonato complexes (9-12) that diminish both enzymatic and chemical reduction rates (13-15). Additional complications associated with U(VI) bio-reduction arise from competing terminal electron acceptors, including nitrate and $\mathrm{Fe}(\mathrm{III})$ hydroxides $(8,16,17)$, and the need for a constant supply of electron donor to preserve anaerobic conditions. Possibly most importantly, authigenic $\mathrm{UO}_{2}$ is subject to reoxidation by common oxidants including molecular oxygen (18-20).

The affinity of Fe(hydr)oxides for trace metals (21), combined with high surface area and prevalence in natural systems, makes them ideal sorbents of uranium. Uranium and Fe occur concomitantly in environmental settings on a variety of time scales. Several studies have noted the association of $\mathrm{U}$ and Fe on geologic timescales on the order of millions of years, (22-24), where $\mathrm{U}$ co-precipitates with $\mathrm{U}, \mathrm{Cu}$ and $\mathrm{Fe}$ under a variety of geochemical settings. Uranium has been found in association with iron and phosphate mineral phases at Oak Ridge, TN nuclear reservation (25) and in mine wastes $(26,27)$, where associations have formed within the last 
century. Despite these observances it remains unresolved how $\mathrm{U}$ is incorporated into these solids and what factors control their solubility. Both $U$ adsorption to oxide surfaces followed by incorporation as well as $\mathrm{U}$ and Fe oxide co-precipitation have been postulated as potential explanations (28-30). Additionally, Duff et al. (31) observed U(VI) incorporation into hematite as the uranate ion $\left(\mathrm{U}^{6+}\right)$.

Accordingly, the principal objective of this research is to determine uranium uptake during reductive transformation of iron oxides and to evaluate both the stability and magnitude of incorporation under cyclically varying redox conditions. Uranium(VI) incorporation into mineral phases has the potential to occur readily under geochemical conditions that do not promote $\mathrm{U}(\mathrm{VI})$ reduction (i.e. in the presence ternary $\mathrm{Ca}-\mathrm{UO}_{2}-\mathrm{CO}_{3}$ complexes). These solids may be stable in the presence of oxidants and reductants, rendering this mechanism a potentially viable pathway to sequester appreciable quantities of uranium stable (i.e., having limited solubility) under a variety of environmental settings.

\section{Methods}

\section{Uranium(VI) Incorporation Experiments}

In order to investigate the stability of U(VI) incorporated into Fe (hydr)oxide structure, we assembled batch systems containing ferrihydrite-coated sand, PIPES buffered distilleddeionized (DDI) water, uranyl acetate, $\mathrm{CaCl}_{2}, \mathrm{KHCO}_{3}$, and varying concentrations of ferrous sulfate $\left(\mathrm{FeSO}_{4}\right)$. Ferrihydrite was prepared according to the method described by Brooks et al (32), and then coated quartz sand as reported previously $(32,33)$. Iron concentration on the sand was approximately $10 \mathrm{~g} \mathrm{Kg}^{-1}$ ( $1 \%$ by weight). The final product had a BET (using $\mathrm{N}_{2}$ isotherm) surface area of $4.8 \pm 0.1 \mathrm{~m}^{2} \mathrm{~g}^{-1}$ ferrihydrite-coated sand. Solutions were made anoxic by boiling 
and cooling under a stream of $\mathrm{N}_{2}$ gas and reactions were performed under anoxic conditions in a glovebag (Coy Laboratory Products) with a $\mathrm{N}_{2}(95 \%): \mathrm{H}_{2}(5 \%)$ atmosphere. Each $125 \mathrm{~mL}$ serum vial contained $1.0 \mathrm{~g}$ of ferrihydrite-coated sand and $100 \mathrm{~mL}$ of medium with $10 \mathrm{mM}$ PIPES, 3.8 $\mathrm{mM} \mathrm{KHCO} 3,0.168 \mathrm{mM}$ uranyl acetate, $\mathrm{UO}_{2}\left(\mathrm{C}_{2} \mathrm{H}_{3} \mathrm{O}_{2}\right)_{2}$, and $3.0 \mathrm{mM} \mathrm{CaCl} \mathrm{Cl}_{2}$ at a $\mathrm{pH}$ of 7.0. All systems were allowed to pre-equilibrate for $1 \mathrm{~h}$ prior to the addition of $\mathrm{Fe}$ (II) (as $\mathrm{FeSO}_{4}$ ) at concentrations of 3 or $10 \mathrm{mM}$. A control experiment with no added $\mathrm{FeSO}_{4}$ was conducted in parallel. Batch systems were assembled and crimp sealed with butyl rubber stoppers (Bellco) in a glovebag and then shaken at $85 \mathrm{rpm}$ at $25^{\circ} \mathrm{C}$ outside of the glovebag. All experiments containing Fe(II) were conducted in duplicate. Experiments without Fe(II) were single systems.

Two different experiments were run in order to investigate both the effect of increased initial reducing period as well as fluctuating redox/aeration conditions on the stability of U(VI) in Fe (hydr)oxide minerals. In the first study, systems were maintained under anoxic conditions for $5,14,30$, or $90 \mathrm{~d}$ (anoxic phase) before being aerated for $5 \mathrm{~d}$ (oxic phase). In the second experiment, systems were kept anoxic for $14 \mathrm{~d}$ before being aerated for $5 \mathrm{~d}$; this process was then repeated for 2 additional cycles so that systems went through a total of three redox cycles; during the first oxic period, total carbonate was also allowed to decrease upon aeration reflecting typical changes upon an anaerobic to aerobic transition. Reaction vessels were aerated by removing rubber stoppers and continuously pumping air into solution through a manifold while the vessels remained stationary on a benchtop. Aqueous and solid-phase samples were collected at the end of each anoxic and oxic phase. Reducing conditions were re-established by purging systems with $\mathrm{N}_{2}$ gas for $\sim 3 \mathrm{~h}$, sealing vials, moving systems to the glovebag, and adding additional $\mathrm{Fe}(\mathrm{II})$. 


\section{Aqueous and Solid Analyses}

Aqueous samples were withdrawn using sterile syringes and filtered through $0.2 \mu \mathrm{m}$ membranes, and analyzed by ICP-OES spectrophotometry (ICP-OES). The detection limit for aqueous uranium was $2 \times 10^{-3} \mathrm{mM}$. Solids were removed from serum vials, rinsed with DDI water, and dried. Solid samples were treated with a $30 \mathrm{mM}$ bicarbonate solution for $24 \mathrm{~h}$ in order to remove and quantify adsorbed U(VI) from the solid surface. Preliminary experiments indicated that this protocol recovered $\sim 64 \%$ of $\mathrm{U}(\mathrm{VI})$ adsorbed to the surface of ferrihydrite and goethite-coated sand. Increasing incubation time and/or bicarbonate concentration did not increase the amount of $\mathrm{U}(\mathrm{VI})$ desorbed. A portion of each solid was then digested with concentrated trace metal grade $\mathrm{HCl}$ to quantify total uranium, iron, and calcium (ICP-OES). The detection limit for solid phase uranium was $0.1 \mathrm{mmol} \mathrm{kg}^{-1}$. The remaining portion of the solid samples was used for XAS, XRD, SEM, TEM, and BET analysis. Sampling procedures following reducing phases were conducted inside a glovebag while sampling following oxic phases was performed on a benchtop.

Uranium and iron X-ray absorption spectra (XAS) were collected on beamline 11-2 at the Stanford Synchrotron Radiation Laboratory (SSRL). Samples were deposited on membranes and sealed with Kapton polyimide film in order to prevent oxidation. Details on anoxic sample preparation are provided in the Supporting Information. Extended X-ray fine structure (EXAFS) and X-ray absorption near edge structure (XANES) spectral scans were averaged and pre- and post-edge subtracted using SixPACK (34). Linear combination fitting was also performed using SixPACK (34). For iron, a set of reference standards was used to perform linear combination $\mathrm{k}^{3}$ - 
weighted EXAFS fitting. The accuracy of Fe EXAFS linear combination fitting was investigated previously (33) and determined to be withing $\sim 5 \%$. Linear combination fitting of $\mathrm{U}_{\mathrm{III}} \mathrm{XANES}$ data was performed using spectra from: (i) the $5 \mathrm{~d}$ no Fe(II) reduced solid, representing U(VI) adsorbed to the surface of Fe(hydr)oxide, (ii) the $5 \mathrm{~d} 3 \mathrm{mM} \mathrm{Fe(II)} \mathrm{oxidized} \mathrm{solid,} \mathrm{representing} \mathrm{U}$ incorporated into Fe (hydr)oxide structure, and (iii) U(IV) standard comprised of pure $\mathrm{UO}_{2}$, representing reduced uranium. The specific structure associated with each of these uranium spectra were established by shell-by-shell EXAFS fitting, considering 4 molecular configurations: an adsorbed geometry, 2 structural incorporation modes, and a reduced (uraninite) phase. Details of the model configuration and EXAFS analysis are provided in the Supporting Information.

\section{Results}

\section{Aqueous Phase}

Uranium (aq) concentration decreases upon reaction of Fe(II) (3 or $10 \mathrm{mM}$ ) with ferrihydrite during anoxic periods persisting for up to $90 \mathrm{~d}$ (Figure 1); under these reaction conditions $\left(4 \mathrm{mM} \mathrm{Ca}\right.$ and $3.8 \mathrm{mM}$ total $-\mathrm{CO}_{3}$ ) the ternary $\mathrm{Ca}-\mathrm{UO}_{2}-\mathrm{CO}_{3}$ complexes comprise $>99$ $\%$ of total dissolved U(VI) (35,36). In systems with $3 \mathrm{mM} \mathrm{Fe(II),} \mathrm{U}_{(\mathrm{aq})}$ decreases from $0.16 \mathrm{mM}$ to below detection limit (BDL) within $15 \mathrm{~d}$. Increasing Fe(II) concentration to $10 \mathrm{mM}$ results in $\mathrm{U}_{(\mathrm{aq})}$ decreasing to BDL within $5 \mathrm{~d}$. In both cases, $\mathrm{U}_{(\mathrm{aq})}$ concentrations remain BDL with prolonged $(90 \mathrm{~d})$ incubations. In similar systems without $\mathrm{Fe}(\mathrm{II}), \mathrm{U}_{(\mathrm{aq})}$ decreases from $0.16 \mathrm{mM}$ to $0.11 \mathrm{mM}$ within $5 \mathrm{~d}$, without further changes for periods up to $90 \mathrm{~d}$ (Figure 1A).

Upon aeration and decrease in total carbonate $\left(0.15 \mathrm{mM}\right.$ total- $\left.\mathrm{CO}_{3}\right), \mathrm{U}_{(\mathrm{aq})}$ remained BDL for systems where ferrihydrite was reacted with $3 \mathrm{mM} \mathrm{Fe(II);} \mathrm{for} \mathrm{systems} \mathrm{where} \mathrm{ferrihydrite} \mathrm{was}$ 
reacted with $10 \mathrm{mM} \mathrm{Fe}(\mathrm{II}), \mathrm{U}_{(\mathrm{aq})}$ rebounds to $0.11-0.15 \mathrm{mM}$ depending on the length of initial anoxic (Fe(II) reaction) period. In control systems (no $\mathrm{Fe}(\mathrm{II})$ ), $\mathrm{U}_{(\mathrm{aq})}$ further decreases to $\sim 0.06$ $\mathrm{mM}$ during suspension aeration (Figure 1B) owing in part to a shift in uranyl species distribution (Table S2, Supporting Information).

In cyclic anoxic-oxic experiments comprised of $14 \mathrm{~d}$ reducing periods followed by $5 \mathrm{~d}$ aeration periods, U(VI) exhibited widely diverging fates (Figure 2). Uranium(VI) (aq) subjected to fluctuating redox conditions, where $10 \mathrm{mM} \mathrm{Fe}(\mathrm{II})$ reacted with ferrihydrite at the beginning of each reducing period, initially decreased to $\mathrm{BDL}$ after the first reduction period but eventually rebounded to $0.16 \mathrm{mM}$ with subsequent oxic and reducing phases. In systems where ferrihydrite reacted with $3 \mathrm{mM} F(\mathrm{II})$ during each reducing period, dissolved uranium remained below detection until the second oxic period before gradually increasing to a final concentration of 0.11 mM. In control systems without added $\mathrm{Fe}(\mathrm{II}), \mathrm{U}_{(\mathrm{aq})}$ decreased to BDL by the end of the first cycle, where it remained throughout the second cycle, before gradually increasing to a final concentration of $0.05 \mathrm{mM}$ by the end of the third redox cycle (Figure 2).

\section{Solid Phase Levels}

Following treatment with $30 \mathrm{mM} \mathrm{KHCO}_{3}$ to remove adsorbed $\mathrm{U}(\mathrm{VI})$ from mineral surfaces, solid-phase uranium in systems containing U(VI) and ferrihydrite reacted with 3 and $10 \mathrm{mM}$ Fe(II) from 5 to $90 \mathrm{~d}$, followed by $5 \mathrm{~d}$ of aeration, varied between 9 and $24 \mathrm{mmol} \mathrm{kg}^{-1}$. Solid phase uranium levels varied depending on $\mathrm{Fe}(\mathrm{II})$ concentration and duration of reducing period (Figure S4, Supporting Information). Solid phase U is greater for ferrihydrite reacted with $3 \mathrm{mM}$ $\mathrm{Fe}(\mathrm{II})$ than with $10 \mathrm{mM} \mathrm{Fe}(\mathrm{II})$ (Figure S4, Supporting Information); values range from 1.2 to 2.4 mmol $\mathrm{kg}^{-1}$ for $3 \mathrm{mM} \mathrm{Fe}(\mathrm{II})$ and from 0.9 to $1.2 \mathrm{mmol} \mathrm{kg}^{-1}$ for $10 \mathrm{mM}$ Fe(II) reacted with 
ferrihydrite. Generally, an increase in initial reducing time correlates with an increase in solid phase uranium; however, for the $3 \mathrm{mM} \mathrm{Fe}(\mathrm{II})$-reacted experiment, an increase from 30 to $90 \mathrm{~d}$ in initial reduction time does not correlate with an increase in solid phase uranium. Following $5 \mathrm{~d}$ aeration, the amount of solid phase uranium is greater for $3 \mathrm{mM} \mathrm{Fe(II)-reacted} \mathrm{systems} \mathrm{than} \mathrm{for}$ $10 \mathrm{mM} \mathrm{Fe(II)-reacted} \mathrm{systems,} \mathrm{regardless} \mathrm{of} \mathrm{initial} \mathrm{reducing} \mathrm{time.} \mathrm{The} \mathrm{largest} \mathrm{difference}$ occurred during the $30 \mathrm{~d}$ experiment where solid phase $U$ is $1.5 \mathrm{mmol} \mathrm{kg}^{-1}$ more in the $3 \mathrm{mM}$ Fe(II)-reacted system.

Uranium remaining in the solid phase following desorption with $\mathrm{KHCO}_{3}$ for systems undergoing oscillating redox cycles varies from $5.5 \mathrm{mmol} \mathrm{kg}^{-1}$ for $10 \mathrm{mM} \mathrm{Fe(II)} \mathrm{reacted} \mathrm{with}$ ferrihydrite following the first reducing phase to $0.8 \mathrm{mmol} \mathrm{U} \mathrm{kg}^{-1}$ for the same system following 3 anoxic-oxic cycles (Figure 3). With the exception of the first reducing phase (R1), more uranium remains in the solid phase for ferrihydrite reacted with $3 \mathrm{mM} \mathrm{Fe}(\mathrm{II})$ than with $10 \mathrm{mM}$ $\mathrm{Fe}(\mathrm{II})$. Although the amount of uranium in the solid phase decreases from 4.5 to $2.2 \mathrm{mmol} \mathrm{\textrm {kg } ^ { - 1 }}$ with subsequent reducing periods in the $3 \mathrm{mM} \mathrm{Fe}(\mathrm{II})$-reacted systems, it remains constant at 2 mmol $\mathrm{U} \mathrm{kg}^{-1}$ throughout each oxic phase (Figure 3). Similarly, in $10 \mathrm{mM} \mathrm{Fe}(\mathrm{II})$-reacted oscillating redox systems, $\mathrm{U}$ remains at a constant level of $0.8 \mathrm{mmol} \mathrm{U} \mathrm{kg}^{-1}$ throughout all oxic phases (Figure 3).

\section{Chemical and Structural State}

Uranium X-ray absorption near edge structure (XANES) spectra from solid samples reveal differences depending on $\mathrm{Fe}(\mathrm{II})$ concentration, initial reducing time, and number of redox cycles (Figure S5, Supporting Information). Uranium $\mathrm{L}_{\text {III }}$ edge position increases from 17,172.5 $\mathrm{eV}$ to $17,176 \mathrm{eV}$ between $\mathrm{U}(\mathrm{IV})$ and $\mathrm{U}(\mathrm{VI})$ standards, while edge position for samples rangeg 
between $17,174.1 \mathrm{eV}$ for solid-phase $\mathrm{U}$ in the $10 \mathrm{mM}$ Fe(II)-reacted system following $90 \mathrm{~d}$ reducing phase, to $17,176 \mathrm{eV}$ for $\mathrm{U}$ without $\mathrm{Fe}(\mathrm{II})$ following $5 \mathrm{~d}$ reducing phase (Table 1). Uranium $L_{\text {III }}$ edges occur at lower energy values in solids collected after reducing phases than in solids following aeration for 3 and $10 \mathrm{mM} \mathrm{Fe(II)-reacted} \mathrm{systems.} \mathrm{Additionally,} \mathrm{the} \mathrm{edge}$ position shifted progressively to lower energies as the initial reducing time increases within samples from $10 \mathrm{mM} \mathrm{Fe(II)-reacted,} \mathrm{suggesting} \mathrm{the} \mathrm{formation} \mathrm{of} \mathrm{U(IV)} \mathrm{after} \mathrm{extended} \mathrm{reaction}$ times (Figure S5, Supporting Information).

\section{Iron Solid Phase}

Changes in solid phase color (not shown) and morphological characteristics (Figure 4) suggested an alteration in iron mineralogy. Ferrihydrite dominates control systems without $\mathrm{Fe}(\mathrm{II})$; goethite laths predominate in $3 \mathrm{mM} \mathrm{Fe}(\mathrm{II})$-reacted systems and are observed in $10 \mathrm{mM}$ systems; lepidocrocite is noted in 3 and $10 \mathrm{mM} \mathrm{Fe(II)} \mathrm{oxic} \mathrm{systems;} \mathrm{finally,} \mathrm{mixed} \mathrm{phases} \mathrm{of}$ fine-grained uraninite and magnetite are observed in $10 \mathrm{mM}$ Fe(II) reduced systems (Figure 4) (37). TEM images of the $10 \mathrm{mM}$ Fe(II)-reacted U(VI)-ferrihydrite system after $90 \mathrm{~d}$ show distinct lattice fringes for magnetite and uraninite (Figure 4E); lattice spacings of 4.85 and $3.19 \AA$ were noted, indicating mixed domains of magnetite and uraninite respectively in discrete regions of the same sample.

Linear combination fitting of iron EXAFS spectra show differences in Fe mineralogy between products despite appreciable amounts of ferrihydrite remaining in all systems (Figure S3, Supporting Information). U(VI)-ferrihydrite systems reacted with $3 \mathrm{mM} \mathrm{Fe(II)} \mathrm{are}$ dominated by goethite under anoxic conditions and goethite and lepidocrocite upon aeration. In addition, magnetite is detected when ferrihydrite was reacted with $10 \mathrm{mM} \mathrm{Fe}$ (II) both during 
anoxic and oxic phases, with the fraction of magnetite decreasing upon aeration. For example, in the $30 \mathrm{~d} 10 \mathrm{mM} \mathrm{Fe}(\mathrm{II})$ experiment, the magnetite fraction decreases from 0.46 to 0.15 between anoxic and oxic phases. During cyclic oxic-anoxic experiments, the surface area of ferrihydrite in the control system (no Fe(II)) decreases from $4.81 \pm 0.10 \mathrm{~m}^{2} \mathrm{~g}^{-1}$ at the start of the experiment to $0.86 \pm 0.004 \mathrm{~m}^{2} \mathrm{~g}^{-1}$ by the end of the third reducing period (R3) (Table S3, Supporting Information).

\section{Discussion}

Uranium in U(VI)-ferrihydrite-Fe(II) systems can be separated into four pools: dissolved $\mathrm{U}(\mathrm{VI})\left(\mathrm{U}_{\mathrm{aq}}\right), \mathrm{U}(\mathrm{VI})$ adsorbed to the surface of Fe(hydr)oxides $\left(\mathrm{U}_{\text {adsorbed }}\right)$ (estimated by $\mathrm{KHCO}_{3}$ desorption treatment), $U$ incorporated into Fe mineral structure $\left(U_{\text {incorporated }}\right)$, and solid phase $\mathrm{U}(\mathrm{IV})\left(\mathrm{UO}_{2(\mathrm{~s})}\right)$ (as detailed above). This framework is used to describe where uranium resides and how relative proportions of $U$ in each pool shift during both anoxic to oxic and cyclic anoxic-oxic experiments.

In systems without $\mathrm{Fe}(\mathrm{II}), \mathrm{U}(\mathrm{VI})$ resides in the aqueous phase $\left(\mathrm{U}_{\mathrm{aq}}\right)$, or is adsorbed to mineral surfaces $\left(\mathrm{U}_{\text {adsorbed }}\right)$ during anoxic to oxic experiments. In 3 and $10 \mathrm{mM} \mathrm{Fe}(\mathrm{II})$-reacted systems following $\geq 14 \mathrm{~d}$ reducing incubation, no $\mathrm{U}(\mathrm{VI})$ is detected in solution; $\mathrm{U}$ in these

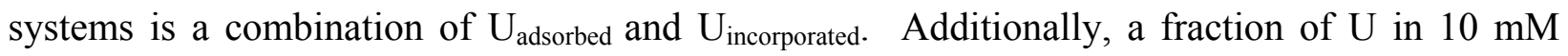
$\mathrm{Fe}(\mathrm{II})$ systems resides as $\mathrm{UO}_{2(\mathrm{~s})}$. When $3 \mathrm{mM} \mathrm{Fe}(\mathrm{II})$ systems are aerated, $\mathrm{U}$ remains as either $\mathrm{U}_{\text {adsorbed }}$ or $\mathrm{U}_{\text {incorporated }}$ with the fraction of $\mathrm{U}_{\text {incorporated }}$ decreasing. By contrast, only a small fraction of $\mathrm{U}$ in $10 \mathrm{mM} \mathrm{Fe}(\mathrm{II})$ systems remains in the structure of Fe minerals as $\mathrm{U}_{\text {incorporated }}$ upon aeration, while some resides as $\mathrm{U}_{\text {adsorbed, }}$ and the largest fraction remains as $\mathrm{U}_{\mathrm{aq}}$. 
In cyclic anoxic-oxic experiments, a decrease in $\mathrm{U}_{(\mathrm{aq})}$ observed in the no $\mathrm{Fe}(\mathrm{II})$ systems, followed by an increase in solution concentration, is attributed to decreasing $\mathrm{U}_{\text {adsorbed }}$ caused by a combination of a decrease in $\mathrm{Fe}$ (hydr)oxide surface area from $4.8 \mathrm{~m}^{2} \mathrm{~g}^{-1}$ to $<1 \mathrm{~m}^{2} \mathrm{~g}^{-1}$ between starting material and solid from the final oxic phase (O3) and a shift in $\mathrm{U}$ species distribution resulting from a change in carbonate levels. The initial increase in adsorption (decreased dissolved concentration) during the first oxic phase (O1) (which is based on a conservative estimate of the full-time series trend from Figure 1 rather than just the $14 \mathrm{~d}$ time point) should be partially influenced by a decrease in uranyl-calcium-carbonato complexes caused by $\mathrm{CO}_{2}$ outgassing during aeration, reflective of a typical changes in transition from an anaerobic to aerobic environment, resulting in a greater proportion of uranyl-carbonato complexes (Table S2, Supporting Information).

In systems reacted with $3 \mathrm{mM} \mathrm{Fe}(\mathrm{II}), \mathrm{U}_{\mathrm{aq}}$ increases from $\mathrm{BDL}$ to $0.08 \mathrm{mM}$ during the second oxic phase $(\mathrm{O} 2)$, before continuing to increase to a final concentration of $0.11 \mathrm{mM}$ (Figure 2). Despite increases in $U_{a q}$, the amount of $U_{\text {incorporated }}$ in the solid phase remains constant during all oxic phases (Figure 3), the increase in aqueous concentration resulting from a decrease in $U_{\text {adsorbed. }}$. The same trend is observed in the $U_{\text {adsorbed }}$ and $U_{\text {incorporated }}$ pools in the 10 $\mathrm{mM} \mathrm{Fe}(\mathrm{II})$-reacted systems during cyclic anoxic-oxic experiments.

A critical factor controlling $\mathrm{U}(\mathrm{VI})$ incorporation into $\mathrm{Fe}($ hydr)oxide structure is the presence of dissolved $\mathrm{Ca}$ and carbonate, which promote the formation of ternary $\mathrm{Ca}-\mathrm{UO}_{2}-\mathrm{CO}_{3}$ complexes, rendering U(VI) resistant to chemical reduction by Fe(II) $(14,15)$. Uranium XANES analysis reveal that as initial reducing time and Fe(II) concentration increase, the fraction of $\mathrm{U}(\mathrm{IV})$ increases, indicating that longer incubations with $\mathrm{Fe}(\mathrm{II})$ promotes not only the formation of magnetite but also reduced uranium phases (Table 1). Indeed, the presence of discrete phases 
of $\mathrm{UO}_{2}$ and magnetite are confirmed by TEM analysis for $10 \mathrm{mM}$ Fe(II) reacted with U(VI)ferrihydrite for $90 \mathrm{~d}$ (Figure 4). The fraction of U(IV) is $\sim 0.5$ for systems reacted with $10 \mathrm{mM}$ Fe(II) for 30 and $90 \mathrm{~d}$; however, this fraction decreases appreciably upon aeration. In cyclic anoxic-oxic experiments reacted with $3 \mathrm{mM} \mathrm{Fe}(\mathrm{II})$, the fraction of oxidized $\mathrm{U}$ incorporated into Fe(hydr)oxide structure remains $>0.9$ for the duration of the study, illustrating the stability of $U$ incorporated into Fe(hydr)oxide minerals reacted with $3 \mathrm{mM} \mathrm{Fe}(\mathrm{II})$.

\section{Implication for U(VI) stability in the presence of Fe(hydr)oxides}

In systems where $3 \mathrm{mM} \mathrm{Fe}(\mathrm{II})$ is reacted with ferrihydrite in the presence of ternary Ca$\mathrm{UO}_{2}-\mathrm{CO}_{3}$ complexes, $\mathrm{U}(\mathrm{VI})$ (or possibly even a $\mathrm{U}(\mathrm{V})$ ) is incorporated into $\mathrm{Fe}(\mathrm{III})$ (hydr)oxide structure during reductive transformations, where it remains stable upon oxidation (Figure 5). By contrast, increasing Fe(II) concentration to $10 \mathrm{mM}$ causes U(VI) initially adsorbed to the surface of ferrihydrite to become both incorporated into Fe(II/III) (hydr)oxide structure and reduced to $\mathrm{U}(\mathrm{IV})$ with subsequent precipitation of $\mathrm{UO}_{2(\mathrm{~s})}$. These solids appear to be less stable in the presence of oxygen, resulting in dissolution of $\mathrm{UO}_{2(\mathrm{~s})}$ and oxidative transformation of $\mathrm{Fe}(\mathrm{II})$ minerals, followed by subsequent release of $\mathrm{U}(\mathrm{VI})$ into solution. Therefore, despite $\mathrm{U}$ uptake by iron minerals reacted with a range of $\mathrm{Fe}(\mathrm{II})$ concentrations, $\mathrm{Fe}(\mathrm{II})$ levels that favor transformations to goethite and lepidocrocite and remain stable in the presence oxygen (i.e. Fe(III) (hydr)oxides) will lead to U sequestered in an optimally stable phase. Iron concentrations of $10 \mathrm{mM}$ will promote the formation of $\mathrm{UO}_{2}$ that is susceptible to reoxidation by $\mathrm{O}_{2}$ despite the presence of $\mathrm{Ca}-\mathrm{UO}_{2}-\mathrm{CO}_{3}$ complexes; however, it should be noted that $\mathrm{Fe}(\mathrm{II})$ concentrations this 
high would likely be occur only in stimulated (added labile organic carbon) reducing environments..

Our results thus reveal that uranium can be incorporated into iron oxides, which may be resistant to oxidative release when incorporated in Fe(III) (hydr)oxide minerals. Transformation of iron oxides through dissolution-precipitation coupled with ternary $\mathrm{Ca}-\mathrm{UO}_{2}-\mathrm{CO}_{3}$ complexes is key to $\mathrm{U}(\mathrm{VI})$ incorporation into stable iron oxide solids. These findings offer a possible explanation for the co-association of $\mathrm{U}(\mathrm{VI})$ and Fe minerals found in nature. The amount of $\mathrm{U}$ sequestered in Fe(hydr)oxides, $4.5 \mathrm{mmol} \mathrm{U}$ per $\mathrm{kg}$ solid for $3 \mathrm{mM} \mathrm{Fe(II)} \mathrm{reacted} \mathrm{with}$ ferrihydrite, is less than that of authigenic $\mathrm{UO}_{2}$ precipitation, where Neiss et al. (15) observed 15 mmol U per kg ferrihydrite-coated sand. Nevertheless, the potential for U incorporated into iron oxide structure to remain stable in the presence of oxygen and under fluctuating redox conditions suggests it may be a means of natural uranium attenuation.

\section{ACKNOWLEDGEMENTS}

We are grateful for the assistance of Dr. G. Li with uranium analysis. This work was supported in part by the Director, Office of Science, Office of Biological and Environmental Research, Environmental Remediation Sciences Program, of the U.S. Department of Energy under Contract No. DE-AC02-05CH11231; support was also provided by OBER-ERSP under grant number ER63609-1021814, and by the Stanford NSF Environmental Molecular Science Institute (NSFCHE-0431425), funded by the National Science Foundation Chemistry and Earth Sciences

Divisions. Portions of this research were carried out at the Stanford Synchrotron Radiation Laboratory, a national user facilities operated by Stanford University on behalf of the U.S. Department of Energy, Office of Basic Energy Sciences under contract DE-AC02-06CH11357.14 


\section{SUPPORTING INFORMATION AVAILABLE}

Details of U EXAFS analysis and fitting parameters (Table S1), uranyl speciation (Table S2), solid phase surface areas (Table S3), solid phase uranium concentrations (Figure S4) and oxidation states (Figure S5), and solid phase speciation of iron oxides (Figure S6) are provided.

\section{References}

(1) Lovley, D. R. Dissimilatory Fe(III) and Mn(IV) reduction. Microbiol Rev 1991, 55, 259287.

(2) Gorby, Y. A.; Lovley, D. R. Enzymatic uranium precipitation. Environ. Sci. Technol. 1992, 26, 205-207.

(3) Liu, C. X.; Gorby, Y. A.; Zachara, J. M.; Fredrickson, J. K.; Brown, C. F. Reduction kinetics of $\mathrm{Fe}(\mathrm{III}), \mathrm{Co}(\mathrm{III}), \mathrm{U}(\mathrm{VI}), \mathrm{Cr}(\mathrm{VI})$, and $\mathrm{Tc}(\mathrm{VII})$ in cultures of dissimilatory metalreducing bacteria. Biotech. Bioeng. 2002, 80, 637-649.

(4) Brooks, S. C.; Carroll, S. L.; Jardine, P. M. Sustained bacterial reduction of Co(III)EDTA(-) in the presence of competing geochemical oxidation during dynamic flow. Environ. Sci. Technol. 1999, 33, 3002-3011.

(5) Fredrickson, J. K.; Zachara, J. M.; Kennedy, D. W.; Duff, M. C.; Gorby, Y. A.; Li, S. M. W.; Krupka, K. M. Reduction of U(VI) in goethite (alpha-FeOOH) suspensions by a dissimilatory metal-reducing bacterium. Geochim. et Cosmochim. Act. 2000, 64, 30853098 .

(6) Anderson, R. T.; Vrionis, H. A.; Ortiz-Bernad, I.; Resch, C. T.; Long, P. E.; Dayvault, R.; Karp, K.; Marutzky, S.; Metzler, D. R.; Peacock, A.; White, D. C.; Lowe, M.; Lovley, D. R. Stimulating the In Situ Activity of Geobacter Species to Remove Uranium from the 15 
Groundwater of a Uranium-Contaminated Aquifer. Appl Environ Microb 2003, 69, 58845891.

(7) Finneran, K. T.; Anderson, R. T.; Nevin, K. P.; Lovley, D. R. Potential for Bioremediation of uranium-contaminated aquifers with microbial U(VI) reduction. Soil \& Sediment Contamination 2002, 11, 339-357.

(8) Wu, W. M.; Carley, J.; Fienen, M.; Mehlhorn, T.; Lowe, K.; Nyman, J.; Luo, J.; Gentile, M. E.; Rajan, R.; Wagner, D.; Hickey, R. F.; Gu, B. H.; Watson, D.; Cirpka, O. A.; Kitanidis, P. K.; Jardine, P. M.; Criddle, C. S. Pilot-scale in situ bioremediation of uranium in a highly contaminated aquifer. 1. Conditioning of a treatment zone. Environ. Sci. Technol. 2006, 40, 3978-3985.

(9) Bernhard, G.; Geipel, G.; Reich, T.; Brendler, V.; Amayri, S.; Nitsche, H. Uranyl(VI) carbonate complex formation: Validation of the Ca2UO2(CO3)(3)(aq.) species. Radiochim. Act. 2001, 89, 511-518.

(10) Kalmykov, S. N.; Choppin, G. R. Mixed Ca2+/UO22+/CO32- complex formation at different ionic strengths. Radiochim. Act. 2000, 88, 603-606.

(11) Bernhard, G.; Geipel, G.; Brendler, V.; Nitsche, H. Speciation of uranium in seepage waters of a mine tailing pile studied by time-resolved laser-induced fluorescence spectroscopy (TRLFS). Radiochim. Act. 1996, 74, 87-91.

(12) Kelly, S.; Kemner, K. M.; Brooks, S. C.; Fredrickson, J. K.; Kennedy, D. W.; Zachara, J. M.; Fendorf, S.; Plymale, A.; Carroll, S. L. Direct evidence for Ca-UO2-CO3 complexation. Abstr Pap Am Chem S 2003, 225, U256. 
(13) Brooks, S. C.; Fredrickson, J. K.; Carroll, S. L.; Kennedy, D. W.; Zachara, J. M.;

Plymale, A. E.; Kelly, S. D.; Kemner, K. M.; Fendorf, S. Inhibition of bacterial U(VI) reduction by calcium. Environ. Sci. Technol. 2003, 37, 1850-1858.

(14) Stewart, B. D.; Neiss, J.; Fendorf, S. Quantifying constraints imposed by calcium and iron on bacterial reduction of uranium(VI). J Environ Qual 2007, 36, 363-372.

(15) Neiss, J.; Stewart, B. D.; Nico, P. S.; Fendorf, S. Speciation-dependent microbial reduction of uranium within iron-coated sands. Environ. Sci. Technol. 2007, 41, 73437348.

(16) Abdelouas, A.; Lutze, W.; Nuttall, E. Reduction of nitrate and uranium by indigenous bacteria. Comptes Rendus de l'Academie des Sciences Serie II A Sciences de la Terre et des Planetes 1998, 327, 25-29.

(17) Wielinga, B.; Bostick, B.; Hansel, C. M.; Rosenzweig, R. F.; Fendorf, S. Inhibition of bacterially promoted uranium reduction: ferric (hydr)oxides as competitive electron acceptors. Environ. Sci. Technol. 2000, 34, 2190-2195.

(18) Wan, J. M.; Tokunaga, T. K.; Brodie, E.; Wang, Z. M.; Zheng, Z. P.; Herman, D.; Hazen, T. C.; Firestone, M. K.; Sutton, S. R. Reoxidation of bioreduced uranium under reducing conditions. Environ. Sci. Technol. 2005, 39, 6162-6169.

(19) Moon, H. S.; Komlos, J.; Jaffe, P. R. Uranium reoxidation in previously bioreduced sediment by dissolved oxygen and nitrate. Environ. Sci. Technol. 2007, 41, 4587-4592.

(20) Wu, W. M.; Carley, J.; Luo, J.; Ginder-Vogel, M. A.; Cardenas, E.; Leigh, M. B.; Hwang, C. C.; Kelly, S. D.; Ruan, C. M.; Wu, L. Y.; Van Nostrand, J.; Gentry, T.; Lowe, K.; Mehlhorn, T.; Carroll, S.; Luo, W. S.; Fields, M. W.; Gu, B. H.; Watson, D.; Kemner, K. M.; Marsh, T.; Tiedje, J.; Zhou, J. Z.; Fendorf, S.; Kitanidis, P. K.; Jardine, P. M.; 
Criddle, C. S. In situ bioreduction of uranium (VI) to submicromolar levels and reoxidation by dissolved oxygen. Environ. Sci. Technol. 2007, 41, 5716-5723.

(21) Brown Jr., G. E.; Trainor, T. P.; Chaka, A. M. In Chemical Bonding at Surfaces and Interfaces; A. Nilsson, L. G. M. P., and J. Norskov, Ed.; Elsevier: New York, 2007; pp 457-509.

(22) Dabous, A. A. Uranium isotopic evidence for the origin of the Bahariya iron deposits, Egypt. Ore Geology Reviews 2002, 19, 165-186.

(23) Sato, T.; Murakami, T.; Yanase, N.; Isobe, H.; Payne, T. E.; Airey, P. L. Iron nodules scavenging uranium from groundwater. Environ. Sci. Technol. 1997, 31, 2854-2858.

(24) Pett-Ridge, J. C.; Monastra, V. M.; Derry, L. A.; Chadwick, O. A. Importance of atmospheric inputs and Fe-oxides in controlling soil uranium budgets and behavior along a Hawaiian chronosequence. Chemical Geology 2007, 244, 691-707.

(25) Stubbs, J. E.; Elbert, D. C.; Veblen, D. R.; Zhu, C. Electron microbeam investigation of uranium-contaminated soils from Oak Ridge, TN, USA. Environ. Sci. Technol. 2006, 40, 2108-2113.

(26) Gomez, P.; Garralon, A.; Buil, B.; Turrero, M. J.; Sanchez, L.; de la Cruz, B. Modeling of geochemical processes related to uranium mobilization in the groundwater of a uranium mine. Science of the Total Environment 2006, 366, 295-309.

(27) Reed, D. T.; Pepper, S. E.; Richmann, M. K.; Smith, G.; Deo, R.; Rittmann, B. E. Subsurface bio-mediated reduction of higher-valent uranium and plutonium. Journal of Alloys and Compounds 2007, 444-445, 376-382.

(28) Murakami, T.; Ohnuki, T.; Isobe, H.; Sato, T. Mobility of uranium during weathering. American Mineralogist 1997, 82, 888-899. 
(29) Gu, B. H.; Brooks, S. C.; Roh, Y.; Jardine, P. M. Geochemical reactions and dynamics during titration of a contaminated groundwater with high uranium, aluminum, and calcium. Geochim. et Cosmochim. Act. 2003, 67, 2749-2761.

(30) Payne, T. E.; Airey, P. L. Radionuclide migration at the Koongarra uranium deposit, Northern Australia - Lessons from the Alligator Rivers analogue project. Physics and Chemistry of the Earth 2006, 31, 572-586.

(31) Duff, M. C.; Coughlin, J. U.; Hunter, D. B. Uranium co-precipitation with iron oxide minerals. Geochim. et Cosmochim. Act. 2002, 66, 3533-3547.

(32) Brooks, S. C.; Taylor, D. L.; Jardine, P. M. Reactive transport of EDTA-complexed cobalt in the presence of ferrihydrite. Geochim. et Cosmochim. Act. 1996, 60, 1899-1908.

(33) Hansel, C. M.; Benner, S. G.; Neiss, J.; Dohnalkova, A.; Kukkadapu, R. K.; Fendorf, S. Secondary mineralization pathways induced by dissimilatory iron reduction of ferrihydrite under advective flow. Geochim. et Cosmochim. Act. 2003, 67, 2977-2992.

(34) Webb, S. M. SIXPack: a graphical user interface for XAS analysis using IFEFFIT. Physica Scripta 2005, 2005, 4p.

(35) Guillaumont, R.; Fanghanel, T.; Neck, V.; Fuger, J.; Palmer, D. A.; Grenthe, I.; Rand, M. H. "Update on the chemical thermodynamics of uranium, neptunium, plutonium, americium, and technichium.," Nuclear Energy Agency, Paris, France., 2003.

(36) Dong, W. M.; Brooks, S. C. Determination of the formation constants of ternary complexes of uranyl and carbonate with alkaline earth metals $(\mathrm{Mg} 2+, \mathrm{Ca} 2+, \mathrm{Sr} 2+$, and Ba2+) using anion exchange method. Environ. Sci. Technol. 2006, 40, 4689-4695.

(37) Cornell, R. M.; Schwertmann, U. The Iron Oxides: Structure, Properties, Reactions, Occurences and Uses; Wiley-VCH, 2003. 
Table 1: Fraction of uranium incorporated into the iron oxide lattice structure, adsorbed on the iron oxide, or reduced to U(IV) (and precipitated as $\mathrm{UO}_{2}$ ). Fractions were determined from XANES linear combination fitting using $5 \mathrm{~d} 3 \mathrm{mM} \mathrm{Fe}$ (II) oxidized sample to represent the incorporated portion, $\mathrm{UO}_{2}$ precipitate as the $\mathrm{U}(\mathrm{IV})$ portion, and $5 \mathrm{~d}$ No $\mathrm{Fe}(\mathrm{II})$ as the adsorbed portion.

\begin{tabular}{lcccc} 
Sample & $\begin{array}{c}\text { Edge position } \\
(\mathbf{e V})\end{array}$ & $\begin{array}{c}\text { Fraction } \\
\text { U(VI) } \\
\text { Incorporated }\end{array}$ & $\begin{array}{c}\text { Fraction } \\
\text { U(IV) }\end{array}$ & $\begin{array}{c}\text { Fraction } \\
\text { U(VI) } \\
\text { Adsorbed }\end{array}$ \\
\hline $\mathbf{5}$ day & & & & \\
No Fe(II) R & 17176.0 & & & \\
$3 \mathrm{mM} \mathrm{Fe}(\mathrm{II}) \mathrm{O}$ & 17175.4 & 0.87 & 0.13 & -
\end{tabular}

\section{4 day}

$\begin{array}{lllll}\text { No Fe(II) O1 } & 17176.1 & - & - & 1.00 \\ \text { No Fe(II) O2 } & 17176.0 & - & - & 1.00 \\ \text { NoFe(II) O3 } & 17176.0 & 0.05 & 0.01 & 0.94 \\ 3 \mathrm{mM} \mathrm{Fe}(I I) \text { O1 } & 17175.3 & 0.96 & 0.04 & - \\ 3 \mathrm{mM} \mathrm{Fe}(\mathrm{II}) \mathrm{O} 2 & 17174.8 & 0.93 & 0.07 & - \\ 3 \mathrm{mM} \mathrm{Fe}(\mathrm{II}) \mathrm{O} 3 & 17174.9 & 0.93 & 0.07 & - \\ 10 \mathrm{mM} \mathrm{Fe}(\mathrm{II}) \mathrm{O} 1 & 17174.9 & 0.92 & 0.08 & - \\ 10 \mathrm{mM} \mathrm{Fe}(\mathrm{II}) \mathrm{R} 1 & 17174.5 & 0.37 & 0.34 & 0.29\end{array}$

\section{0 day}

$\begin{array}{lllll}3 \mathrm{mM} \mathrm{Fe}(\mathrm{II}) \mathrm{R} & 17174.2 & 0.59 & 0.41 & - \\ 10 \mathrm{mM} \mathrm{Fe}(\mathrm{II}) \mathrm{O} & 17174.9 & 0.84 & 0.16 & - \\ 10 \mathrm{mM} \mathrm{Fe}(\mathrm{II}) \mathrm{R} & 17174.2 & 0.39 & 0.47 & 0.14\end{array}$

\section{0 day}

$\begin{array}{lllll}\text { No Fe(II) O } & 17176.2 & 0.09 & - & 0.91 \\ \text { No Fe(II) R } & 17176.1 & 0.09 & - & 0.91 \\ 3 \mathrm{mM} \mathrm{Fe}(\mathrm{II}) \mathrm{O} & 17175.1 & 0.92 & 0.08 & - \\ 10 \mathrm{mM} \mathrm{Fe}(\mathrm{II}) \mathrm{O} & 17175.3 & 0.99 & 0.01 & - \\ 10 \mathrm{mM} \mathrm{Fe}(\mathrm{II}) \mathrm{R} & 17174.1 & 0.47 & 0.46 & 0.07\end{array}$



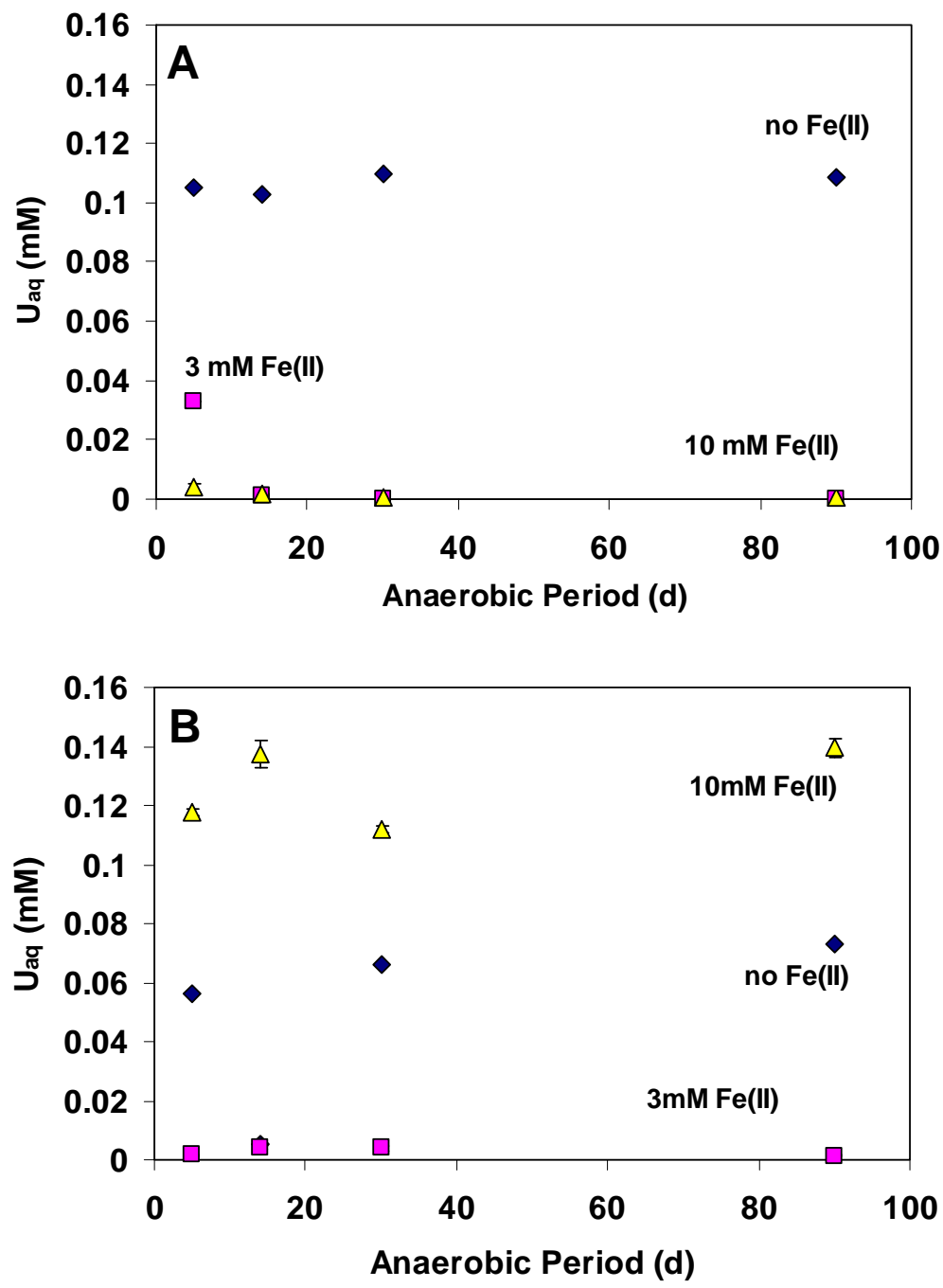

Figure 1. Dissolved uranium concentration following A) 5 to $90 \mathrm{~d}$ anoxic period and B) $5 \mathrm{~d}$ of aeration post reaction of 0,3 , and $10 \mathrm{mM} \mathrm{Fe}(\mathrm{II})$ with ferrihydrite. 


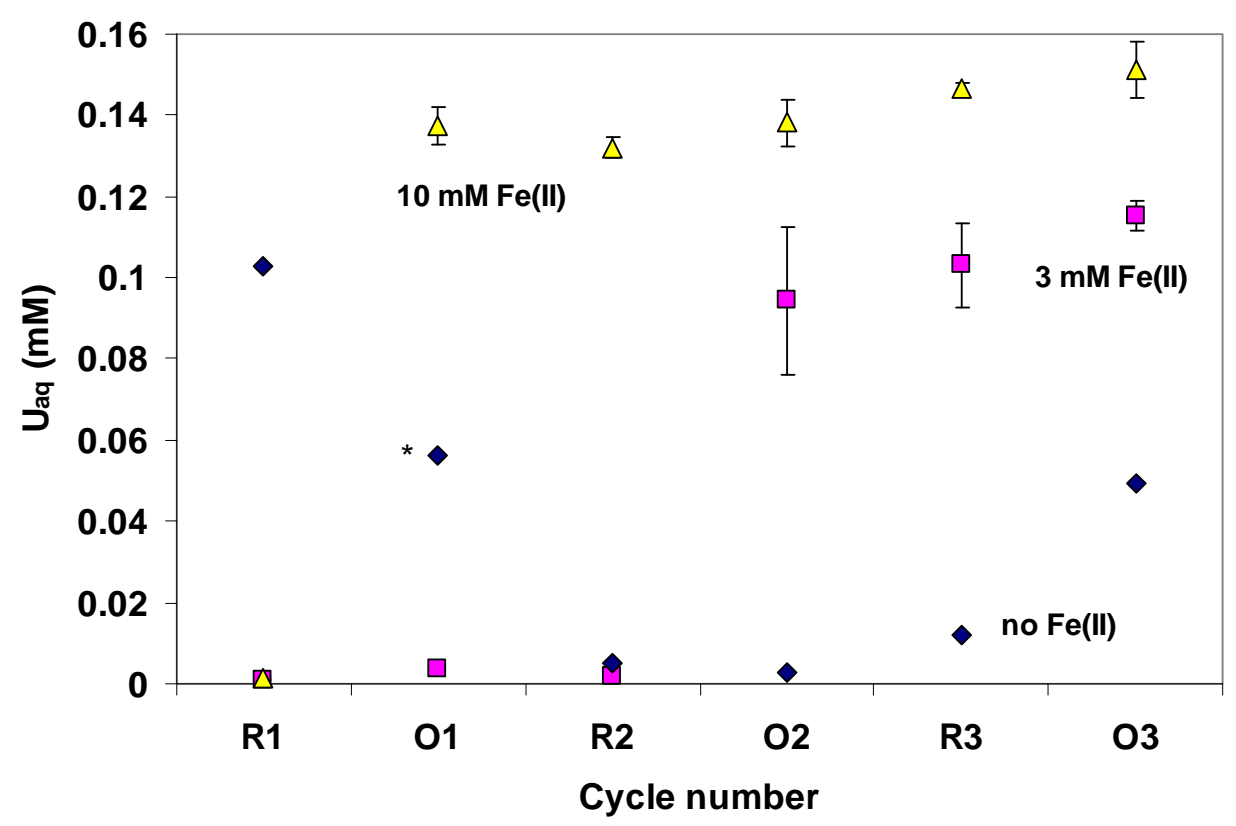

Figure 2. Uranium concentration (aqueous) following redox cycles (14 $\mathrm{d}$ anoxic with $\mathrm{Fe}(\mathrm{II})$ addition and $5 \mathrm{~d}$ oxic under aeration) for 0,3 , and $10 \mathrm{mM} \mathrm{Fe}(\mathrm{II})$ reacted with ferrihydrite ( $\mathrm{R}$ denotes reducing (reaction with $\mathrm{Fe}(\mathrm{II})$ ) phase and $\mathrm{O}$ indicates oxic phase). * For the no Fe(II), O1 data point, the overall data trend from the time series in Figure 1 was used to represent an average value to provide a more conservative comparison than the anomalously low $14 \mathrm{~d}$ value from the data series. 


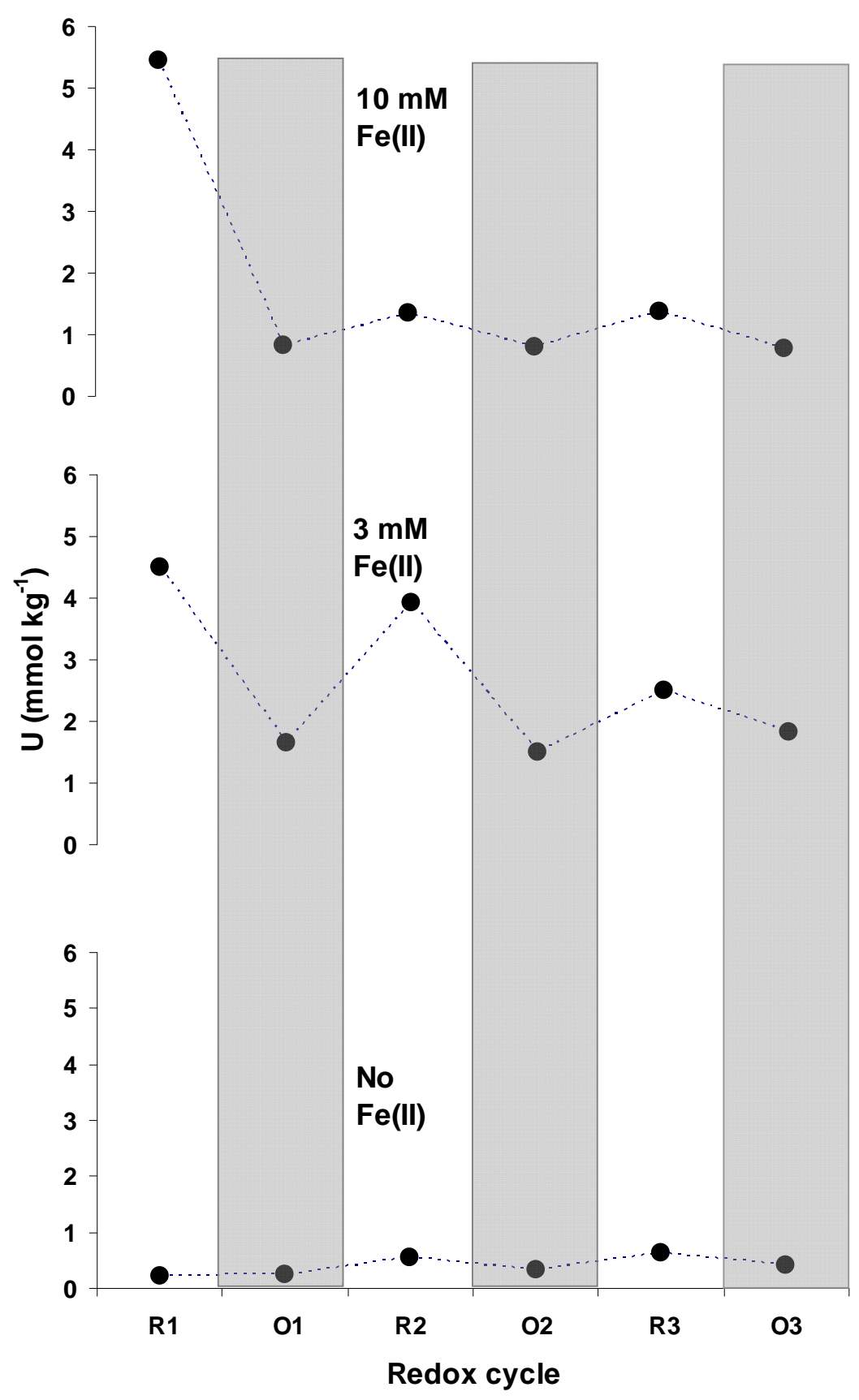

Figure 3. Solid phase uranium after treatment with $\mathrm{KHCO}_{3}$ following redox cycles (14 d anoxic with $\mathrm{Fe}(\mathrm{II})$ addition and $5 \mathrm{~d}$ oxic under aeration) for $3 \mathrm{mM}$ $\mathrm{Fe}(\mathrm{II})$ and $10 \mathrm{mM} \mathrm{Fe}(\mathrm{II})$ reacted with ferrihydrite (R denotes reducing (reaction with $\mathrm{Fe}(\mathrm{II}))$ phase and $\mathrm{O}$ indicates oxic phase). 


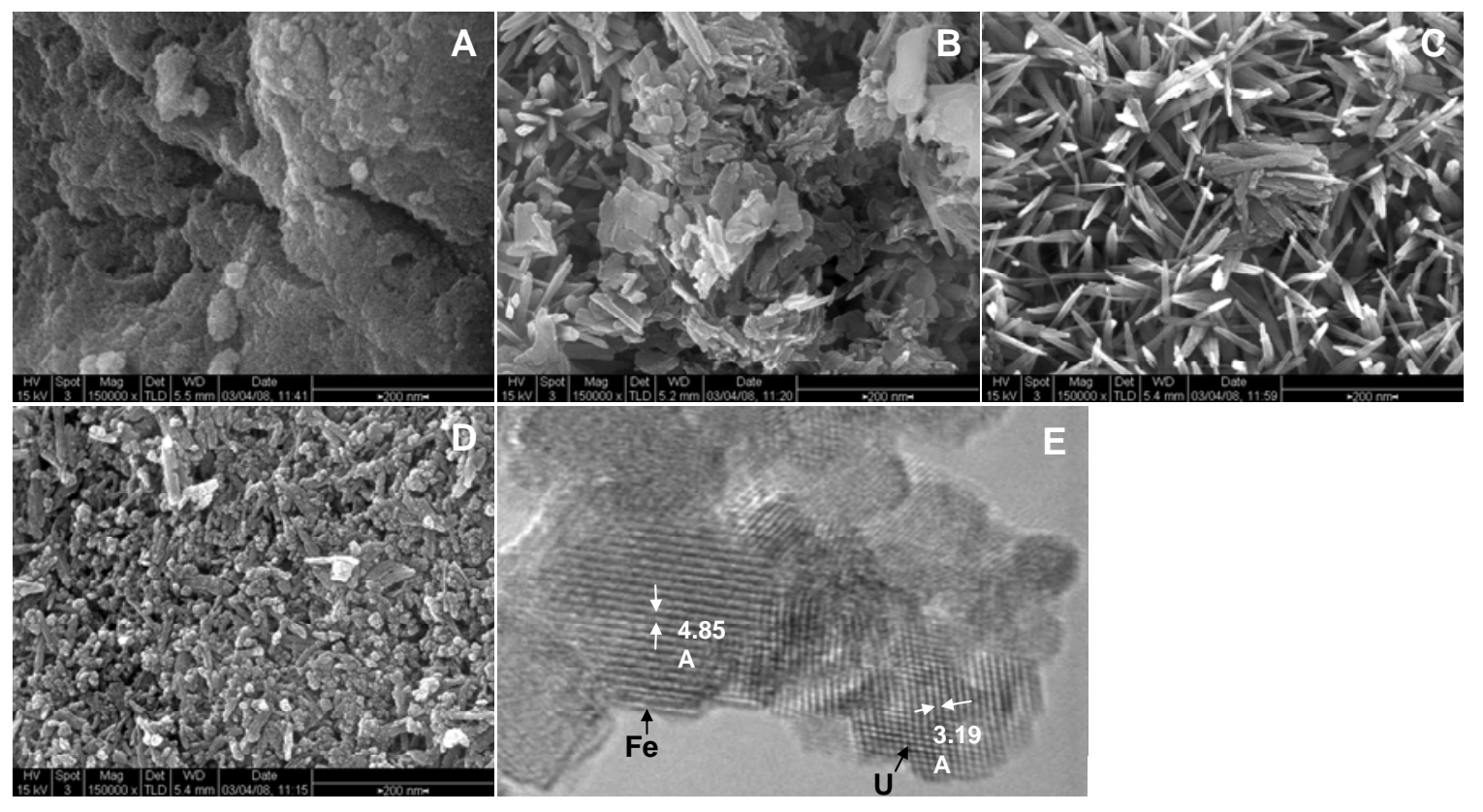

Figure 4. Scanning and transmission electron micrographs of solids resulting from ferrihydrite reacted with varying concentrations of $\mathrm{Fe}(\mathrm{II})$ during anoxic-oxic and repetitive redox cycle experiments: A) $14 \mathrm{~d}$ no Fe(II) O2, B) 14 d 3 mM Fe(II) R2, C) 14 d 10 mM Fe(II) O1, and D, E) 90 d $10 \mathrm{mM} \mathrm{Fe}(\mathrm{II}) \mathrm{R}$, ( $\mathrm{R}$ denotes reducing (reaction with $\mathrm{Fe}(\mathrm{II})$ ) phase and $\mathrm{O}$ indicates oxic phase). 


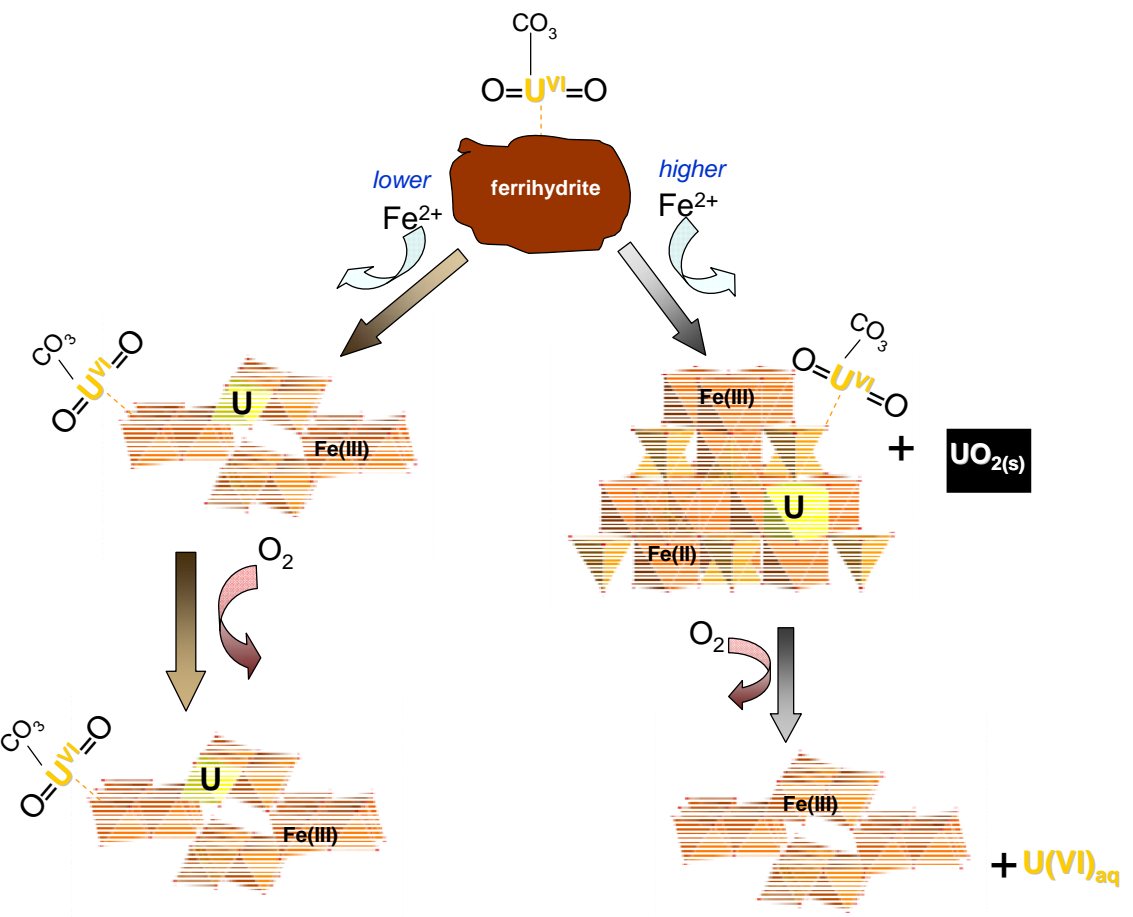

Figure 5. Schematic diagram depicting dominant mechanisms of U(VI)-ferrihydrite system reacted with $\mathrm{Fe}(\mathrm{II})$. 


\section{SUPPORTING INFORMATION}




\section{Anoxic Sample Preparation Details}

Anoxic samples were mounted on filter paper, enclosed in two layers of Kapton tape and placed in an anoxic box inside a glovebag before being transported to the synchrotron facility. Upon arrival, samples were placed back in a glovebag and removed one at a time for analysis. Monitoring of a U(IV) standard (prepared and treated in the same manner) showed that the edge position remained constant over a $\sim 5-6 \mathrm{~h}$ scanning period, indicating no oxidation during data acquisition. Additionally, we have tested this procedure with various oxygensensitive compounds and found the protocol to preserve the oxidation state of the constituents.

\section{Uranium EXAFS Fitting Details}

Uranium EXAFS scans were averaged, pre- and post-edge subtracted, and normalized using Athena (1-3). Chi functions were extracted using the auto-background routine with a threshold value of 1.4 to 1.6. Shell-by-shell fitting was performed in SixPACK (4) using phase and amplitude parameters calculated by Feff7. The physical model of uranium in these systems is comprised of three components: uranium is i) adsorbed to Fe(hydr)oxide surfaces, ii) incorporated into Fe(hyrd)oxide structure, and iii) reduced to U(IV) as a discrete phase. From these three physical scenarios, four crystallographic models were constructed. The first describes adsorption, two describe incorporation in two slightly different crystal orientations, and the fourth describes reduced uranium as $\mathrm{UO}_{2}$. These fitting models were compared to the data and were found to provide satisfactory fits. Single and multiple scattering paths included in the four models, along with the mathematical constraints placed on the coordination numbers $(\mathrm{CN})$ and Debye Waller factors $\left(\sigma^{2}\right)$, are presented in Table S1 (Table S1, Supporting Information). The CNs were constrained to ideal values based on either known crystal 
structures $(3,5)$ or previously published models $(1,6-9)$. The $\sigma^{2}$ s were grouped roughly by distance from the central atom and identity of the scattering atom. Constraining the CNs and $\sigma^{2}$ s minimized the number of free variables allowing for better resolved fitting results. The four different fitting models are described in detail below.

The Adsorbed model was constructed from previously published results of U adsorption onto various Fe oxides (1,6-9). It consists of an axial O shell containing two atoms, a split equatorial shell containing four shorter and two longer U-O bonds, a carbonate shell, and an Fe shell. The Adsorbed and Incorporated model 1 consists of two sub-models and includes all paths from the Adsorbed model other than the Fe shell which was removed, and the carbonate shell which was increased from $2 \mathrm{C}$ to $3 \mathrm{C}$ 's per U. In addition, the model includes the paths expected from $U$ substituted for Fe in a goethite or magnetite structure. The additional paths for the "incorporated" portion of the model were generated by taking the crystallographic data for goethite or magnetite (5), using Atoms (3) , and then replacing the central absorbing Fe with a U atom. In magnetite, the octahedral, as opposed to tetrahedral, Fe was replaced with U. The $\mathrm{CN}$ constraints allow the proportion of $\mathrm{U}$ in each environment to vary while maintaining the appropriate ideal CN relationships within a given environment. The Adsorbed and Incorporated model 2 is almost identical to the model 1 except that the split equatorial oxygen shell for adsorbed $U$ was consolidated into a single shell containing 6 oxygens. All three of these models include the appropriate multiple scatter paths (MS). Finally, the Reduced model consists of the $\mathrm{O}$ and $\mathrm{U}$ scattering paths expected for $\mathrm{UO}_{2}$.

Synchrotron-based XRD data were collected at SSRL on beamline 11-3 and calibrated with lanthanum hexaboride. Fit2D and Jade were used to process XRD data. Scanning electron microscopy (SEM) images were collected at 15, 000 and 35,000x magnification on an 
FEI XL30 Sirion SEM with FEG source. Transmission electron microscopy (TEM) images

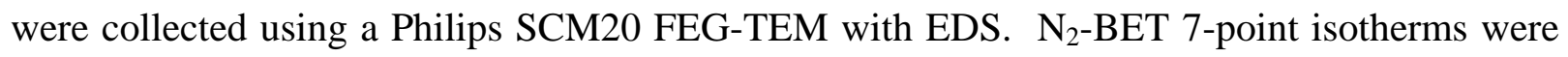
performed on a Micromeritics Accelerated Surface Area and Porosity System. 
S1: Coordination number $(\mathrm{N})$ and Debye-Waller factor $\left(\sigma^{2}\right)$ constraints for uranium EXAFS spectral fitting for $5 \mathrm{~d}$, no Fe(II) and 3 and $10 \mathrm{mM} \mathrm{Fe(II)} \mathrm{reacted} \mathrm{with} \mathrm{ferrihydrite} \mathrm{solids.}$

\section{Coordination Number (CN) Constraints Debye-Waller $\left(\sigma^{2}\right)$ \\ Constraints}

\begin{tabular}{|c|c|c|c|c|c|c|c|}
\hline & Ideal & $\begin{array}{l}\text { No } \\
\text { Fe(II) }\end{array}$ & $\begin{array}{l}3 \mathrm{mM} \\
\mathrm{Fe}(\mathrm{II})\end{array}$ & $\begin{array}{l}10 \mathrm{mM} \\
\mathrm{Fe}(\mathrm{II})\end{array}$ & $\begin{array}{l}\text { No } \\
\text { Fe (II) }\end{array}$ & $\begin{array}{l}3 \mathrm{mM} \\
\mathrm{Fe}(\mathrm{II})\end{array}$ & $\begin{array}{l}10 \mathrm{mD} \\
\mathrm{Fe}(\mathrm{II})\end{array}$ \\
\hline \multicolumn{8}{|c|}{ Surface Bound } \\
\hline $\mathrm{U}-\mathrm{O}_{\mathrm{ax}}$ & 2 & $\mathrm{~N}_{\text {sorb }}$ & $2-\left(\mathrm{N}_{\mathrm{ppt}} / 3\right)$ & ------ & $\sigma_{1}^{2}$ & $\sigma_{1}^{2}$ & ------ \\
\hline $\mathrm{U}-\mathrm{O}_{\mathrm{eq} 1}$ & 4 & $2 * \mathrm{~N}_{\mathrm{sorb}}$ & $6-\mathrm{N}_{\mathrm{ppt}}$ & ------ & $\sigma_{2}^{2}$ & $\sigma_{2}^{2}$ & ------ \\
\hline $\mathrm{U}-\mathrm{O}_{\mathrm{eq} 2}$ & 2 & $\mathrm{~N}_{\text {sorb }}$ & ------ & ------ & $\sigma_{3}{ }^{2}$ & ----- & ------ \\
\hline U-C & 2 & $\mathrm{~N}_{\text {sorb }}$ & $(3 / 2)^{*} N_{\text {sorb }}$ & ------ & $\sigma_{4}^{2}$ & $\sigma_{2}^{2}$ & ------ \\
\hline U-Fe & 1 & $\mathrm{~N}_{\mathrm{Fe}}$ & ------ & ------ & $\sigma_{5}^{2}$ & ------ & ------ \\
\hline
\end{tabular}

Axial MS

\begin{tabular}{|c|c|c|c|c|c|c|c|}
\hline $\mathrm{U}-\mathrm{O}_{1}-\mathrm{O}_{2}$ & 2 & $\mathrm{~N}_{\text {sorb }}$ & $\mathrm{N}_{\text {sorb }}$ & ------ & $2 * \sigma_{1}^{2}$ & $2^{*} \sigma_{1}^{2}$ & ------ \\
\hline $\mathrm{U}-\mathrm{O}_{1}-\mathrm{U}-\mathrm{O}_{2}$ & 2 & $\mathrm{~N}_{\text {sorb }}$ & $\mathrm{N}_{\text {sorb }}$ & ------ & $2 * \sigma_{1}^{2}$ & $2 * \sigma_{1}^{2}$ & ------ \\
\hline $\mathrm{U}-\mathrm{O}_{1}-\mathrm{U}-\mathrm{O}_{1}$ & 2 & $\mathrm{~N}_{\text {sorb }}$ & $\mathrm{N}_{\text {sorb }}$ & ------ & $2 * \sigma_{1}{ }^{2}$ & $2 * \sigma_{1}^{2}$ & ---- \\
\hline corporat & & & & & & & \\
\hline $\mathrm{J}-\mathrm{O}$ & 6 & ------- & $\mathrm{N}$ & - & ------ & & ------ \\
\hline
\end{tabular}

\section{Goethite}

U-Fe

U-O

$\mathrm{U}-\mathrm{Fe}$

$\mathrm{U}-\mathrm{Fe}$

$\begin{array}{ll}2 & ----- \\ 1 & ----- \\ 2 & ----- \\ 4 & -----\end{array}$

$(1 / 3) *\left(\mathrm{~N}_{\mathrm{ppt}}-\mathrm{N}_{\mathrm{m}}\right)$

$(1 / 6) *\left(\mathrm{~N}_{\mathrm{ppt}}-\mathrm{N}_{\mathrm{m}}\right)$

$(1 / 3) *\left(\mathrm{~N}_{\mathrm{ppt}}-\mathrm{N}_{\mathrm{m}}\right)$

$(4 / 6) *\left(\mathrm{~N}_{\mathrm{ppt}} \mathrm{N}_{\mathrm{m}}\right)$

$\begin{array}{ccc}----- & ----- & \sigma_{3}{ }^{2} \\ ---- & ----- & \sigma_{3}{ }^{2} \\ ---- & ----- & \sigma_{4}{ }^{2} \\ ---- & ----- & \sigma_{4}{ }^{2}\end{array}$

Magnetite

U-Fe

6

$\mathrm{N}_{\mathrm{m}}$

$\sigma_{3}^{2}$

\section{Octahedral}

MS
$\mathrm{U}-\mathrm{O}_{1}-\mathrm{O}_{2}$
6

$\begin{array}{ll}------ & \mathrm{N}_{\mathrm{ppt}} \\ ----- & \mathrm{N}_{\mathrm{ppt}} \\ ----- & \mathrm{N}_{\mathrm{ppt}}\end{array}$
三
$\begin{array}{ll}---- & 2 * \sigma_{1}{ }^{2} \\ ---- & 2 * \sigma_{1}{ }^{2} \\ ---- & 2 * \sigma_{1}{ }^{2}\end{array}$

\section{Uraninite}

U-O

$\mathrm{N}$
$\mathrm{N}_{\mathrm{U}}$

$\sigma_{1}{ }^{2}$ 
S2: Aqueous uranyl species distribution for initial anoxic reaction (3.8 $\mathrm{mM} \mathrm{CO}_{3}$-tot) and subsequent oxic/aerated periods (0.15 $\mathrm{mM} \mathrm{CO}_{3}$-tot): $\mathrm{pH}=7$ and $[\mathrm{U}(\mathrm{VI})]=0.168 \mathrm{mM}$.

\section{Concentration (mM)}

\begin{tabular}{lll} 
Species & $\mathbf{C O}_{3}$-tot $=\mathbf{3 . 8}$ & $\mathbf{C O}_{3}$-tot $=\mathbf{3 . 8}$ \\
\hline$\left(\mathrm{UO}_{2}\right)_{2} \mathrm{CO}_{3}(\mathrm{OH})_{3}{ }^{-}$ & $9.03 \times 10^{-6}$ & $7.63 \times 10^{-2}$ \\
$\mathrm{UO}_{2}\left(\mathrm{CO}_{3}\right)_{2}{ }^{2-}$ & $5.63 \times 10^{-4}$ & $1.43 \times 10^{-4}$ \\
$\mathrm{UO}_{2}\left(\mathrm{CO}_{3}\right)_{3}{ }^{4-}$ & $3.41 \times 10^{-4}$ & $1.73 \times 10^{-6}$ \\
$\mathrm{UO}_{2} \mathrm{CO}_{3(\mathrm{aq})}$ & $7.18 \times 10^{-5}$ & $9.24 \times 10^{-4}$ \\
$\mathrm{Ca}_{2} \mathrm{UO}_{2}\left(\mathrm{CO}_{3}\right)_{3(\mathrm{aq})}$ & 0.13 & $7.72 \times 10^{-4}$ \\
$\mathrm{CaUO}_{2}\left(\mathrm{CO}_{3}\right)_{3}{ }^{2-}$ & $4.3 \times 10^{-2}$ & $2.40 \times 10^{-4}$
\end{tabular}

S3: BET surface areas of reacted solids showing a decrease in $0 \mathrm{mM} F e(I I)$ solid sample surface area as number of oxic-anoxic cycles increase; R denotes reducing (reaction with $\mathrm{Fe}(\mathrm{II})$ ) phase and $\mathrm{O}$ indicates oxic phase.

\begin{tabular}{ll} 
Sample & SA $\left(\mathbf{m}^{\mathbf{2}} \mathbf{g}^{-\mathbf{1}}\right.$ solid $)$ \\
\hline Ferrihydrite 0 d & $4.8051 \pm 0.1024$ \\
15d No Fe(II) R2 & $1.9819 \pm 0.0491$ \\
15d No Fe (II) R3 & $0.8591 \pm 0.0039$ \\
15d No Fe(II) O3 & $<0.1$
\end{tabular}




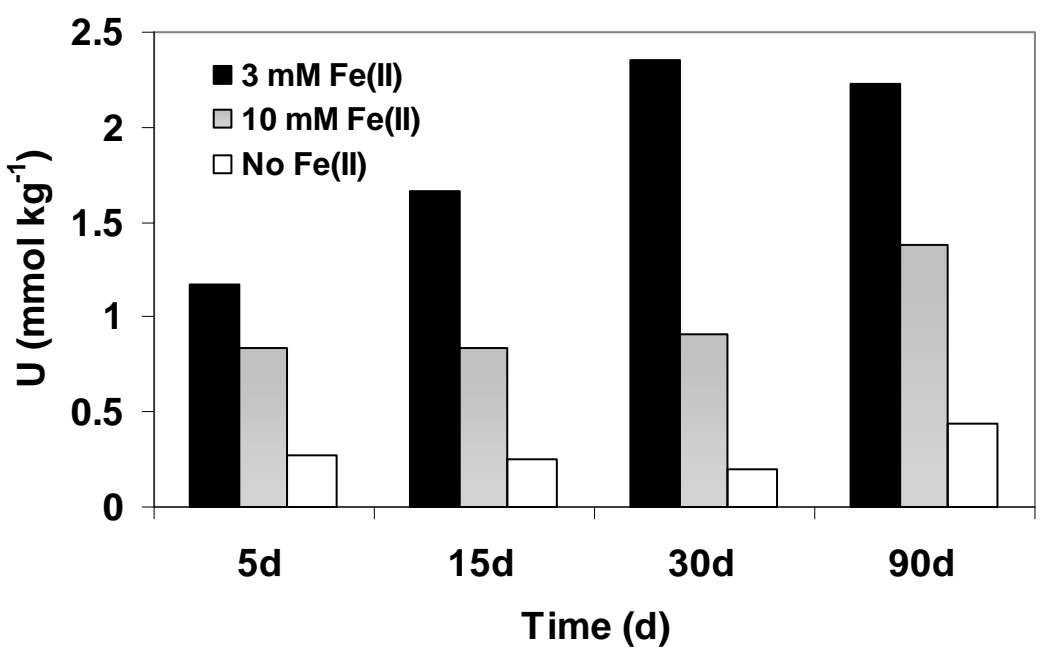

S4. Solid phase uranium after treatment with $\mathrm{KHCO}_{3}$ for ferrihydrite systems reacted with $3 \mathrm{mM} \mathrm{Fe(II)} \mathrm{and} 10 \mathrm{mM} \mathrm{Fe(II)} \mathrm{for} 5$ to $90 \mathrm{~d}$ followed by $5 \mathrm{~d}$ of aeration. 

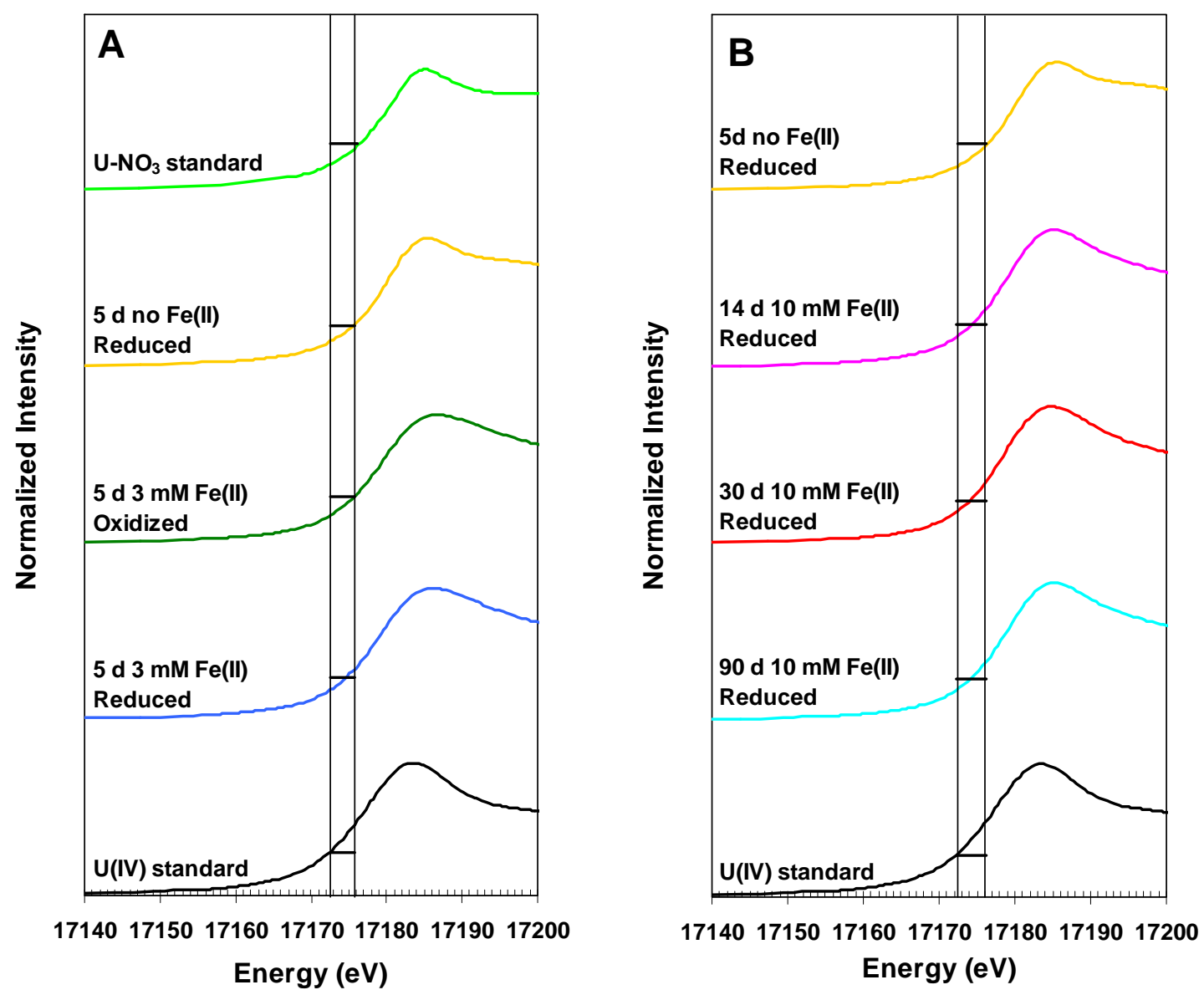

S5. Uranium XANES spectra for solids collected during A) 5 d anoxic-oxic experiment for 0,3 , and $10 \mathrm{mM} \mathrm{Fe(II)} \mathrm{reacted} \mathrm{with} \mathrm{ferrihydrite} \mathrm{and} \mathrm{B)} 10 \mathrm{mM} \mathrm{Fe(II)} \mathrm{reacted} \mathrm{with}$ ferrihydrite for 14, 30, and $90 \mathrm{~d}$. 


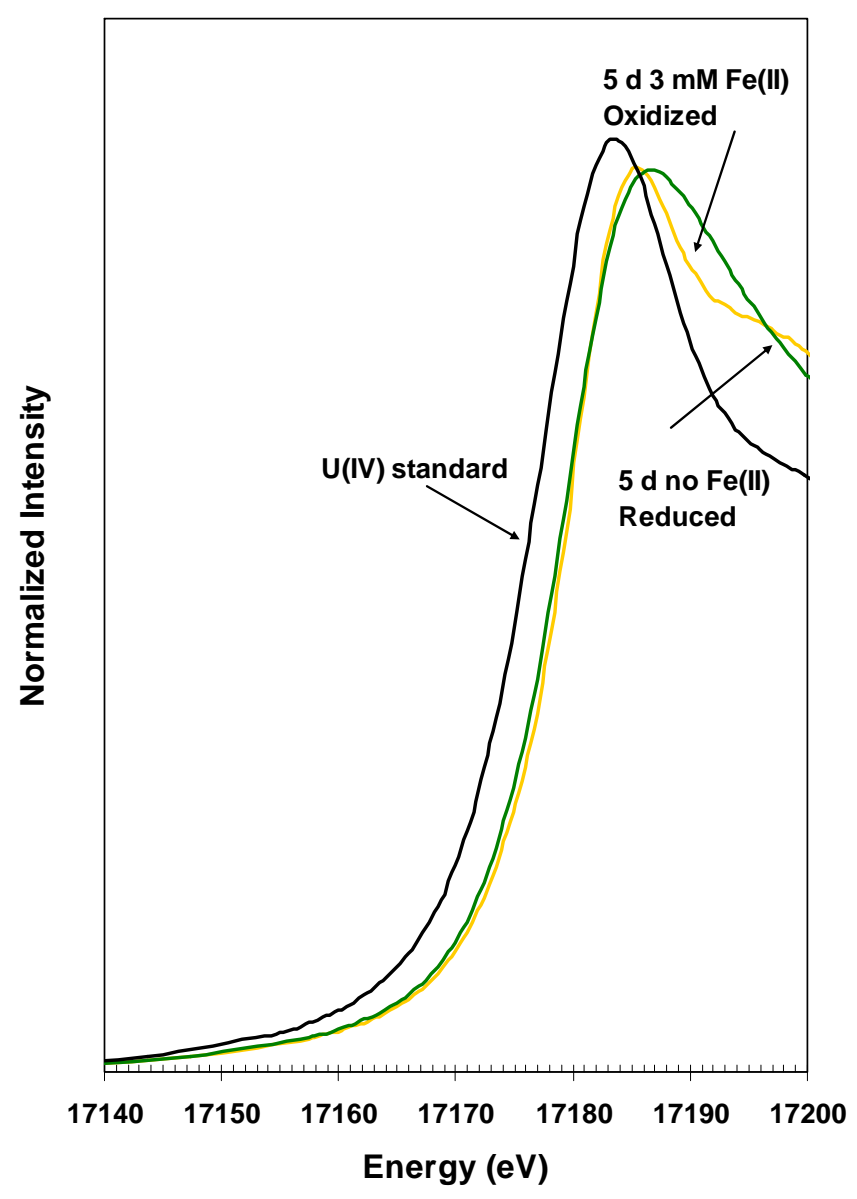

S6. Uranium XANES spectra for solids used as standards in linear combination fitting. 


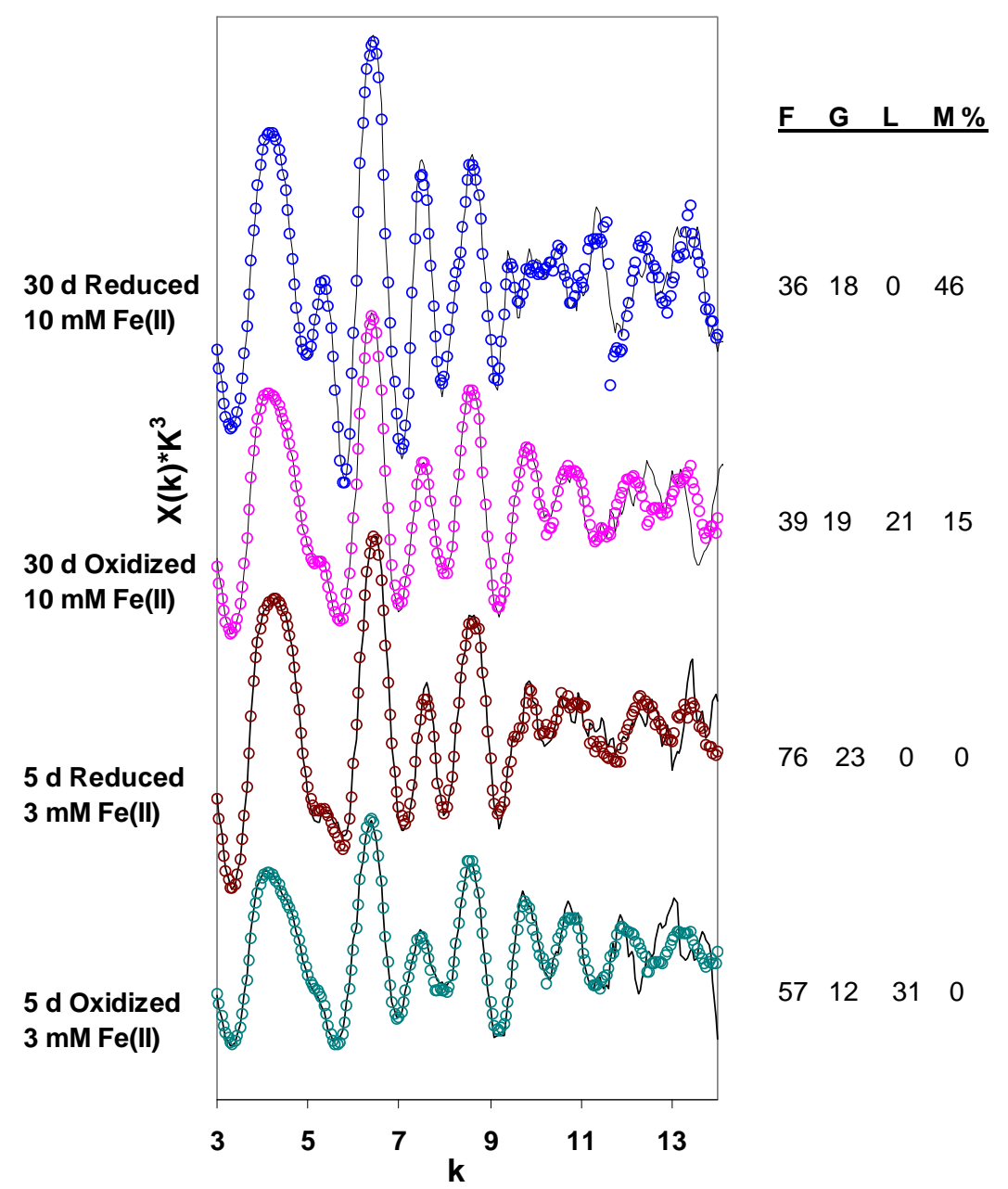

F=ferrihydrite, $G=$ goethite, L=lepidocrocite, M=magnetite

S7. Linear combination fitting of iron EXAFS of solids collected during 30 and $5 \mathrm{~d}$ anoxic-oxic experiments for 3 and $10 \mathrm{mM}$ Fe(II) reacted with ferrihydrite. 


\section{References}

(1) Bargar, J. R.; Reitmeyer, R.; Davis, J. A. Spectroscopic confirmation of uranium(VI)carbonato adsorption complexes on hematite. Environ. Sci. Technol. 1999, 33, 24812484.

(2) Newville, M. EXAFS analysis using FEFF and FEFFIT. Journal of Synchrotron Radiation Eleventh International Conference on X-Ray Absorption Fine Structure. XAFS XI, 2631 July 2000, Ako, Japan 2001, 8, 96-100.

(3) Ravel, B.; Newville, M. ATHENA, ARTEMIS, HEPHAESTUS: data analysis for X-ray absorption spectroscopy using IFEFFIT. Journal of Synchrotron Radiation 2005, 12, 537-541.

(4) Webb, S. M. SIXPack: a graphical user interface for XAS analysis using IFEFFIT. Physica Scripta 2005, 2005, 4p.

(5) Cornell, R. M.; Schwertmann, U. The Iron Oxides: Structure, Properties, Reactions, Occurences and Uses; Wiley-VCH, 2003.

(6) Waite, T. D.; Davis, J. A.; Payne, T. E.; Waychunas, G. A.; Xu, N. Uranium(VI) adsorption to ferrihydrite - application of a surface complexation model. Geochim. et Cosmochim. Act. 1994, 58, 5465-5478.

(7) Reich, T.; Moll, H.; Arnold, T.; Denecke, M. A.; Hennig, C.; Geipel, G.; Bernhard, G.; Nitsche, H.; Allen, P. G.; Bucher, J. J.; Edelstein, N. M.; Shuh, D. K. An EXAFS study of uranium(VI) sorption onto silica gel and ferrihydrite. Journal of Electron Spectroscopy and Related Phenomena Second German - Russian Symposium on Electron and X-Ray Spectroscopy, 2-5 Nov. 1997, Berlin, Germany 1998, 96, 237-243. 
(8) Bargar, J. R.; Reitmeyer, R.; Lenhart, J. J.; Davis, J. A. Characterization of U(VI)carbonato ternary complexes on hematite: EXAFS and electrophoretic mobility measurements. Geochim. et Cosmochim. Act. 2000, 64, 2737-2749.

(9) Moyes, L. N.; Parkman, R. H.; Charnock, J. M.; Vaughan, D. J.; Livens, F. R.; Hughes, C. R.; Braithwaite, A. Uranium uptake from aqueous solution by interaction with goethite, lepidocrocite, muscovite, and mackinawite: An X-ray absorption spectroscopy study. Environ. Sci. Technol. 2000, 34, 1062-1068. 